\title{
IMPLEMENTASI PSIKOLOGI PENDIDIKAN MENUJU RESILIENSI AKADEMIK PADA MAHASISWA
}

\section{EDUCATION PSYCHOLOGY IMPLEMENTATION TOWARDS STUDENTS'ACADEMIC RESILIENCY}

\author{
Alma Yulianti ${ }^{1}$, Mudjiran $^{2}$ \& Herman Nirwana ${ }^{3}$ \\ ${ }^{1}$ Fakultas Psikologi UIN Sultan Syarif Kasim Riau \\ 2,3 Fakultas Ilmu Pendidikan Jurusan BK Universitas Negeri Padang \\ almayulianti@rocketmail.com
}

Received: $14^{\text {th }}$ January 2021; Revised: $30^{\text {th }}$ January 2021; Accepted: $5^{\text {th }}$ February 2021

\begin{abstract}
Resilience is a personal quality that allows individuals to rise up when facing difficulties, especially for students who are undergoing their final semester in college. Various challenges and difficulties caused by thesis work are problems that cannot be avoided for every student. This study is focused on studying the role of academic resilience in final year students. The research subjects consisted of 7 undergraduate students from 19 to 24 years of age. Students are expected to have resilience in facing academic challenges called academic resilience. Academic resilience is defined as the ability of students to withstand difficult conditions, bounce back from adversity, overcome difficulties, and adapt positively to academic pressure and demands.
\end{abstract}

Keywords: Implementation, Academic Resilience, Education

\begin{abstract}
ABSTRAK
Resiliensi adalah kualitas pribadi yang memungkinkan individu untuk bangkit ketika menghadapi kesulitan khsususnya pada mahasiswa yang menjalani semester akhir di perguruan tinggi. Berbagai tantangan dan kesulitan yang disebabkan oleh pengerjaan skripsi adalah permasalahan yang tidak dapat dihindari bagi setiap mahasiswa. Studi ini difokuskan pada kajian peran ketahanan akademik pada mahasiswa tingkat akhir. Subjek penelitian terdiri dari 7 mahasiswa sarjana dari rentang usia 19 hingga 24 tahun. Mahasiswa diharapkan memiliki ketahanan dalam menghadapi tantangan akademik yang disebut resiliensi akademik. Resiliensi akademik yang dirumuskan kemampuan mahasiswa untuk bertahan pada kondisi yang sulit, bangkit kembali dari keterpurukan, mengatasi kesulitan, dan beradaptasi secara positif terhadap tekanan dan tuntutan akademik
\end{abstract}

Kata Kunci: Implementasi, Resiliensi Akademik, Pendidikan 


\section{PENDAHULUAN}

Pendidikan memiliki peran yang sangat penting dalam mempersiapkan siswa untuk menghadapi perubahan zaman. Dalam menjalankan proses pendidikan para siswa seringkali dihadapkan dengan berbagai macam permasalahan yang dapat menyulitkan siswa untuk berhasil di sekolah, permasalahan ini dapat disebabkan oleh berbagai faktor seperti tingginya tingkat kriminalitas, kemiskinan, angka putus sekolah, penyalahgunaan obat-obatan, kesehatan dan permasalahan sosial lainnya (Babbi \& Byrne; Jeffries; Schensul; Van Horn dalam Speight, 2009; Waxman, Gray \& Padron, 2003). Seiring dengan perkembangan zaman maka permasalahan dalam dunia pendidikan pun semakin kompleks, hal ini tentunya menjadi tantangan bagi penyelenggaraan pendidikan di Indonesia mengingat pentingnya pendidikan bagi setiap manusia.

Pendidikan tidak hanya sekadar mempersiapkan siswa untuk dapat menghadapi kehidupan saat ini tetapi juga dipersiapkan untuk kehidupan yang akan datang. Saat ini telah banyak penelitian yang menunjukkan pencapaian prestasi siswa dari berbagai Negara berhasil melalui berbagai macam rintangan sehingga mampu menyelesaikan studinya tepat waktu (Castro, dkk, 2011). Mereka mampu memusatkan perhatian dan konsentrasi pada riset yang dilakukan dengan penuh dan sungguh-sungguh, membuat strategi belajar yang tepat disertai komitmen tinggi alam melaksanakannya. Mereka yang mampu menunjukkan pengelolaan positif terhadap berbagai kondisi yang mendatangkan tekanan dan kemudian berhasil menyelesaikan studi tepat waktu adalah mahasiswa yang diketahui memiliki resiliensi dalam proses belajar, atau yang disebut sebagai resiliensi akademik (Fuerth, 2008; Boatman, 2014).

Lazarus (1993, dalam Tugade dan Fredricson, 2004) mendefinisikan resiliensi sebagai koping efektif dan adaptasi positif terhadap kesulitan dan tekanan. Sementara menurut Richardson 
(2002), resiliensi adalah proses koping terhadap stresor, kesulitan, perubahan, maupun tantangan yang dipengaruhi oleh faktor protektif. Resiliensi mencerminkan bagaimana kekuatan dan ketangguhan yang ada dalam diri seseorang. Resiliensi psikologis ditandai dengan kemampuan untuk bangkit dari pengalaman emosional yang negatif. Seorang yang resilien akan berusaha untuk menghadapi dan kemudian bangkit dari berbagai kondisi stres dengan kemampuan yang dimiliki (Block dan Kremen, 1996, dalam Tugade dan Fredricson, 2004). Resiliensi akademik merupakan resiliensi dalam proses belajar, yakni sebuah proses dinamis yang mencerminkan kekuatan dan ketangguhan seseorang untuk bangkit dari pengalaman emosional negatif, saat menghadapi situasi sulit yang menekan atau mengandung hambatan signifikan dalam aktivitas belajar yang dilakukan. Resiliensi akademik terjadi ketika mahasiswa menggunakan kekuatan internal maupun eksternalnya untuk mengatasi berbagai pengalaman negatif, menekan dan menghambat selama proses belajar, sehingga mereka mampu beradaptasi dan melaksanakan setiap tuntutan akademik dengan baik (Boatman, 2014). Mengetahui lebih jauh tentang bagaimana resiliensi akademik dapat dicapai, akan memberikan sumbangan besar terhadap upaya yang dapat dilakukan untuk memberikan pendampingan proses studi mahasiswa doktoral secara tepat (Boatman, 2014).

Sejauh ini telah ditemukan 3 penelitian yang memotret tentang resiliensi akademik pada mahasiswa doctoral, yaitu penelitian Fuerth (2008), Castro, Cavajos, Garcia, dan Castro (2011), dan Boatman (2014), namun ketiganya dilakukan di luar Indonesia. Perbedaan tempat penelitian, terlebih pada negara yang juga berlainan rumpun, tentu akan membawa konsekuensi terhadap perbedaan situasi yang dihadapi oleh mahasiswa, kurikulum pendidikan, dan berbagai pola kebiasaan yang berlaku di dalamnya. Salah satu bidang penelitian yang mempunyai implikasi penting untuk meningkatkan pendidikan bagi siswa yaitu berkaitan dengan resiliensi siswa, atau 
mereka yang berhasil di sekolah meskipun dengan kondisi yang kurang baik. Selama beberapa dekade terakhir, penelitian tentang resiliensi telah banyak dilakukan dalam mengembangkan bidang psikopatologi, psikologi, sosiologi dan antropologi (Waxman, Gray\&Padron, 2003).

Resiliensi di bidang pendidikan menyajikan sebuah kerangka kerja untuk memahami mengapa beberapa anak-anak yang beresiko dapat berhasil di sekolah, sedangkan yang lainnya tidak (Geste, 2010). Alva (dalam Waxman, Gray dan Padron, 2003) menggunakan istilah resiliensi akademik untuk menggambarkan siswa yang mampu mempertahankan tingkat prestasi yang tinggi, motivasi dan kinerja, meskipun dengan adanya peristiwa yang menekan dan kondisi yang menempatkan mereka pada resiko untuk melakukan hal buruk di sekolah dan terancam dikeluarkan dari sekolah. masalah akademis maupun non-akademis (Yesamine, 2000).

Namun pada kenyataannya, tidak sedikit mahasiswa yang merasa terbebani dan mengalami berbagai kesulitan dalam mengerjakan skripsi. Kesulitan-kesulitan tersebut, seperti kesulitan dalam hal mencari tema, judul, sampel, alat ukur yang digunakan, kesulitan mendapatkan referensi, keterbatasan waktu penelitian, proses revisi yang berulang-ulang, dosen pembimbing yang sibuk dan sulit ditemui, lamanya umpan balik dari dosen pembimbing ketika menyelesaikan skripsi, dan lain-lain (Maritapiska dalam Wulandari, 2012).

Dalam menghadapi berbagai kesulitan yang diakibatkan oleh pengerjaan skripsi, mahasiswa membutuhkan peran resiliensi. Resiliensi adalah kapasitas individu untuk menghadapi dan mengatasi serta merespon secara positif kondisikondisi tidak menyenangkan yang tidak dapat dihindari, dan memanfaatkannya untuk memperkuat diri sehingga mampu beradaptasi terhadap perubahan, tuntutan, dan kekecewaan yang muncul dalam kehidupan. 
Hasil penelitian Hartuti dan Mangunsong (2009), bahwa faktor protektif eksternal resiliensi yang mempunyai pengaruh yang signifikan adalah pengharapan yang tinggi dari lingkungan. Pengharapan yang tinggi dari lingkungan didapatkan mahasiswa dari orang-orang yang berada di sekitarnya, salah satunya adalah teman sebaya. Chaplin (2009), mengatakan bahwa teman sebaya adalah teman yang seusia. Santrock (2005), menambahkan bahwa teman sebaya diartikan sebagai individu dengan tingkat usia atau tingkat kedewasaan yang sama. Menurut Papalia, Old, dan Feldman (2009), teman sebaya merupakan sumber kasih sayang, pengertian, simpati, dan tuntutan moral, yang digunakan sebagai tempat untuk bereksperimen serta sebagai sarana untuk mencapai kemandirian dan otonomi dari orang tua. Dukungan sosial teman sebaya adalah suatu pemberian bantuan atau dukungan. Berdasarkan berbagai riset yang telah dilakukan oleh para peneliti, terdapat berbagai faktor yang mempengaruhi terbentuknya resiliensi akademik pada remaja usia sekolah atau disebut siswa. Siswa dapat menjadi resilien jika memiliki tempramen positif termasuk di dalamnya tingkat aktivitas tinggi dan respon positif terhadap orang lain, motivasi berprestasi, memperoleh dukungan yang tinggi dan hubungan sosial yang baik dari keluarga, guru dan teman sebaya, menikmati datang ke sekolah dan lebih terlibat dalam kegiatan sekolah,

\section{METODE PENELITIAN}

Penelitian ini menggunakan pendekatan kualitatif dengan jenis penelitian studi kasus. Data dari seluruh partisipan dalam penelitian ini akan dianalisis sebagai satu kesatuan unit. Partisipan terdiri dari 7 orang mahasiswa Strata 1 Program Studi Psikologi Universitas X yang telah menyelesaikan studi. Masa studi partisipan bervariasi dari 4 hingga 6 tahun. Pengumpulan data 
dalam penelitian ini dilakukan dengan menggunakan metode wawancara dengan pedoman umum dan lembar isian data awal. Sementara teknik analisis data yang digunakan pada penelitian ini adalah analisis tematik data driven yang dikembangkan oleh Boyatzis (1998). Skala Resiliensi Akademik disusun berdasarkan aspek dari Reivich dan Shatte (2002), yaitu pengendalian emosi, kontrol terhadap impuls, optimisme, kemampuan menganalisis masalah, empati, efikasi diri, dan pencapaian.

\section{HASIL PENELITIAN}

Resiliensi akademik memotret bagaimana siswa atau mahasiswa mengatasi berbagai pengalaman negatif, menekan dan menghambat selama proses belajar, sehingga berhasil memenuhi setiap tuntutan akademik dengan baik. Hasil analisis data menunjukkan bahwa pencapaian resiliensi akademik terjadi dengan adanya adaptasi positif yang mampu dimunculkan oleh mahasiswa setiap kali berhadapan dengan kesulitan. Adaptasi positif yang dimaksud akan dipaparkan dengan menjelaskan terlebih dahulu pengalaman negatif yang dirasakan partisipan dan menjadi kesulitan besar dalam proses studinya.

Terdapat tiga pengalaman negatif yang utama dirasakan oleh mahasiswa dalam penelitian ini dan cukup menguras energi mereka untuk mengatasinya. Ketiga pengalaman tersebut meliputi: (1) Problem pembagian waktu yang sedang dijalani; (2) Problem dengan pembimbing dan penguji; dan (3) Problem dalam pelaksanaan penelitian. Secara personal problem ini tidak lepas dari perbedaan karakter dan pengalaman antar individu. Pada problem ketiga tentang pelaksanaan penelitian, mahasiswa mengakui kelemahan ini dimiliki dan memberi hambatan signifikan dalam proses penelitian yang dilakukan. Keterbatasan penguasaan metodologi dan pengalaman lapangan 
menjadi catatan tersendiri yang nantinya patut dicarikan solusi agar problem serupa dapat diantisipasi sejak awal.

Mahasiswa dengan ketahanan yang tinggi yang mampu bertahan menghadapi kondisi sulit dan terus berusaha menyelesaikan tugas akhirnya. Ketahanan memiliki makna yang dekat dengan istilah psikologi yaitu resiliensi. Bonanno (dalam Feldman, 2013), menerangkan bahwa resiliensi adalah kemampuan untuk bertahan, mengatasi, dan benar-benar berkembang setelah menghadapi kesulitan yang mendalam. Cutuli dan Masten (dalam Lopez, 2009), menjelaskan bahwa dalam perkembangan manusia, penelitian resiliensi difokuskan pada tiga situasi, yaitu berada dalam keadaan kemalangan yang signifikan (stress resistance), bangkit dari keterpurukan setelah mengalami trauma atau pengalaman yang sangat mengganggu (bouncing back), berhasil kembali kedalam keadaan normal (normalization).

\section{KESIMPULAN}

Dalam beberapa kasus, resiliensi mengarah pada pola perilaku sehat setelah mengalami kemalangan atau ancaman. Mahasiswa diharapkan memiliki ketahanan dalam menghadapi tantangan akademik yang disebut resiliensi akademik (Gizir, 2004). Resiliensi akademik adalah kemampuan mahasiswa untuk bertahan pada kondisi yang sulit, bangkit kembali dari keterpurukan, mengatasi kesulitan, dan beradaptasi secara positif terhadap tekanan dan tuntutan akademik. Martin dan Marsh (dalam Hartuti \& Mangunsong, 2009), menjelaskan bahwa mahasiswa yang resilien secara akademik adalah mahasiswa yang mampu secara efektif menghadapi empat keadaan, yaitu kejatuhan (setback), tantangan (challenge), kesulitan (adversity), dan tekanan (pressure) dalam konteks akademik. Empat keadaan tersebut juga 
ditemukan dalam hal pembuatan tugas akhir, terdapat faktor internal dan eksternal yang menjadi kendala bagi mahasiswa.

\section{DAFTAR PUSTAKA}

Boyatzis, R.E. (1998). Transforming Qualitative Information: Thematic Analysis And Code Development.

Boatman, M. (2014). Academically Resilient Minority Doctoral Students Who Experienced Poverty And Parental Substance Abuse. http://scholarworks.waldenu.edu/dissertations.

Castro, V., Cavajos Jr. J., Garcia, E.E., \& Castro, A.Y. (2011). The Road To Doctoral Success And Beyond. International Journal Of Doctoral Studies, Vol. 6, 2012, 52- 77.

Gizir, C. A. (2004). Academic Factors Contributing To The Academic Achievement Of Eight Grade Student Of Proverity. Thesis. Istanbul: Departement Educational Science of Middle East 177-182 182 Technical University. Diunduh dari http://www.etd.lib.metuedu.tr/upload/3/12605533 /index.pdf.

Fuerth, K.M. (2008). Resiliency In Academically Successful Latina Doctoral Students: Implication For Advocacy. Graduate Theses and Dissertation. http://scholarcommons.usf.edu/etd/255.

Reivich, K. \& Shatte, A. (2002).The Resilience Factor: 7 Essential Skills For Overcoming Life's Inevitable Obstacles. New York : Broadway Books.

Richardson, G. E. (2002). The Metatheory of Resilience and Resiliency. Journal of Clinical Psychology, 58(3), 307-321.

Tugade, M.M., Fredricson, B.L., \& Barrett, L.F. (2004). Psychological Resilience And Positive Emotional Granurality: Examining The Benefits Of Positive Emotions On Coping And Health. Journal Of Personality, 72:26, December 2004. 